\title{
MASTER
}

\section{Solar Energy and the Oil Refining Industry}
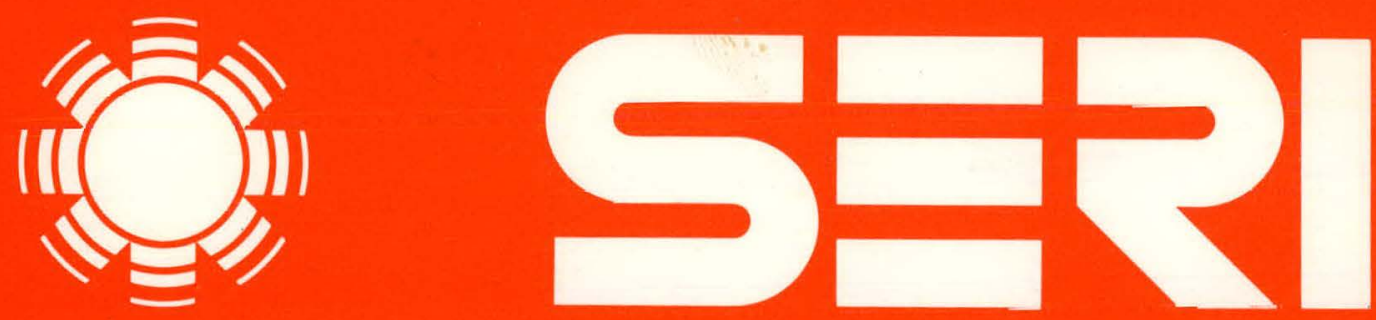

Solar Energy Research Institute

A Division of Midwest Research Institute

1617 Cole Boulevard

Golden, Colorado 80401

Operated for the

U.S. Department of Energy

under Contract No. EG-77-C-01-4042 


\section{DISCLAIMER}

This report was prepared as an account of work sponsored by an agency of the United States Government. Neither the United States Government nor any agency Thereof, nor any of their employees, makes any warranty, express or implied, or assumes any legal liability or responsibility for the accuracy, completeness, or usefulness of any information, apparatus, product, or process disclosed, or represents that its use would not infringe privately owned rights. Reference herein to any specific commercial product, process, or service by trade name, trademark, manufacturer, or otherwise does not necessarily constitute or imply its endorsement, recommendation, or favoring by the United States Government or any agency thereof. The views and opinions of authors expressed herein do not necessarily state or reflect those of the United States Government or any agency thereof. 


\section{DISCLAIMER}

Portions of this document may be illegible in electronic image products. Images are produced from the best available original document. 
Printed in the United Staies of America

Available from:

National Technical Information Service

U.S. Department of Commerce

5285 Port Royal Road

Springfield, VA 22161

Price:

Microfiche $\$ 3.00$

Printed Copy $\$ 4.50$

\section{NOTICE}

This report was prepared as an account of work sponsored by the United States Government. Neither the United States nor the United States Department of Energy, nor any of their employees, nor any of their contractors, subcontractors, or their employees, makes any warranty, express or implied, or assumes any legal liability or responsibility for the accuracy, completeness or usefulness of any information, apparatus, product or process disclosed, or represents that its use would not infringe privately owned rights. 
SERI /TR-733-562

UC CATEGORY: UC-58b, 59b, 92

SOLAR ENERGY AND THE

- OIL REFINING INDUSTRY

\section{E. KENNETH MAY}

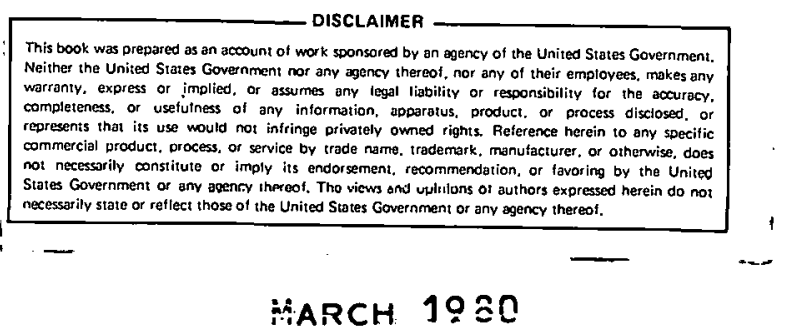

PREPARED UNDER TASK NO. 3473.20

\section{Solar Energy Research Institute}

1536 Cole Rnılevard

Golden, Colorado 80401

A Division of Midwest Research Institute

Prepared for the

U.S. Department of Energy

Contract No. EG $\cdot 77 \cdot C \cdot 01 \cdot 4042$ 
THIS PAGE

\section{WAS INTENTIONALLY LEFT BLANK}




\section{FOREWORD}

This work was supported by the Department of Energy under the Office of Planning and Technology Transfer, Task No. 5121, and the Agricultural and Industrial Systems Branch, Task No. 3424. The report is part of an overall SERI eff ort to determine the characteristics of industrial energy use, and the potential for solar energy to provide industrial process heat.

The previous work on this subject by SERI staff members D. Dougherty and J. Wright is acknowledged. I would also like to thank SERI personnel $\mathrm{K}$. Brown and D. Kearney, and J. Williams of Insights West and his Process Consultant, S. Krueger, for their helpful comments in preparing this report.

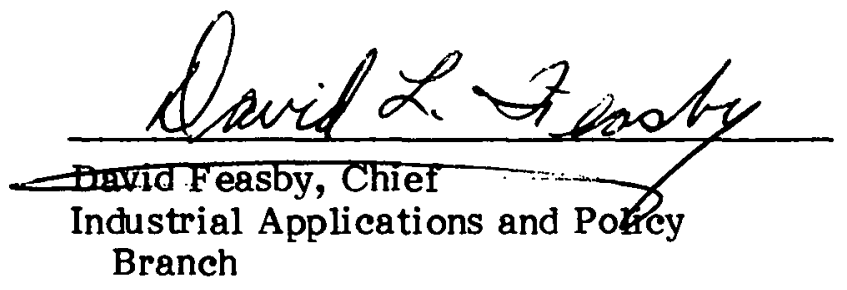

Approved for

SOLAR ENERGY RESEARCH INSTITUTE

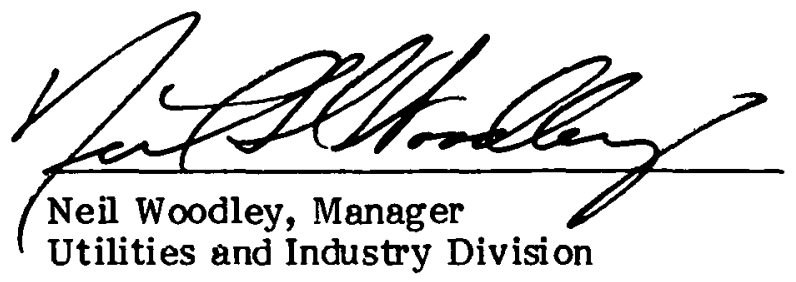


THIS PAGE WAS INTENTIONALLY LEFT BLANK 
This paper surveys process heat requirements of the major petroleum refinery processes. Previous studies have overestimated requirements for process heat at high temperatures. Twenty-two percent of the process heat in a refinery is estimated to be consumed below $550^{\circ} \mathrm{F}$, and $62.5 \%$ is consumed between $550^{\circ}$ and $1100^{\circ} \mathrm{F}$.

A refinery derives approximately $40 \%$ of its total energy supply and $50 \%$ of its process heat from natural gas and fuel oil. However, technological constraints limit the application of alternatives such as coal or solar energy to processes operating below $700^{\circ} \mathrm{F}$, equivalent to about $25 \%$ of process heat requirements. Therefore, because the refinery industry consumes $98.5 \%$ of the total process heat used in the range $550-1100^{\circ} \mathrm{F}$, the potential for the displacement of present fuels supplying energy to industrial processes operating at $700-1100^{\circ} \mathrm{F}$ is severely limited. Future curtailments of natural gas supplies and advances in "bottom of the barrel" oil processing technology could produce strong incentives to develop alternatives to the buming of liquid fuels for low-temperature processes.

Energy derived from coal or solar radiation is most appropriately used at a central facility to heat a heat-transfer fluid, which is then heat exchanged with the process medium. Steam could also be produced using the same technology. The cost of installing caal-burning equipment can be up to eight times the cost of the equivalent gas- or oilburning facility. However, the major obstacle to the use of coal is environmental.

A simple analysis of the perform ance of a central-receiver solar system, without storage, and sized to deliver a maximum of $25 \%$ of process heat needs, indicates that $4.1 \%$ of refinery fuel needs could be displaced. For the entire industry, this is equivalent to $57,000 \mathrm{BPD}$ of fuel oil. If long-term cost goals are achieved, capital expenditures to realize these savings would amount to $\$ 6.5$ billion. 
THIS PAGE

WAS INTENTIONALLY

LEFT BLANK 


\section{TABLE OF CONTENTS}

$\underline{\text { Page }}$

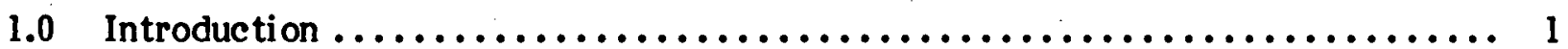

2.0 Energy Consumption in Major Refinery Processes $\ldots \ldots \ldots \ldots \ldots \ldots \ldots \ldots$. 7

2.1 Crude Distillation $. . \ldots \ldots \ldots \ldots \ldots \ldots \ldots \ldots \ldots \ldots \ldots \ldots \ldots, 7$

$2.2 \quad$ Vacuum Distillation $\ldots \ldots \ldots \ldots \ldots \ldots \ldots \ldots \ldots \ldots \ldots \ldots \ldots \ldots, 7$

2.3 Gas Fractionation $. \ldots \ldots \ldots \ldots \ldots \ldots \ldots \ldots \ldots \ldots \ldots \ldots \ldots \ldots, 8$

2.4 Catalytic Reforming.............................. 8

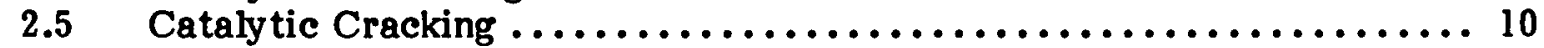

2.6 Processing Catalytic Cracking Off-Gases .................... 12

2.7 Catalytic Hydrotreating and Hydrorefining $\ldots \ldots \ldots \ldots \ldots \ldots \ldots \ldots \ldots \ldots$

2.8 Visbreaking and Coking $\ldots \ldots \ldots \ldots \ldots \ldots \ldots \ldots \ldots \ldots \ldots \ldots \ldots \ldots \ldots \ldots \ldots, 12$

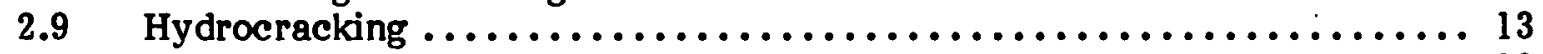

2.10 Summary $\ldots \ldots \ldots \ldots \ldots \ldots \ldots \ldots \ldots \ldots \ldots \ldots \ldots \ldots \ldots \ldots \ldots \ldots \ldots, 13$

3.0 Alternatives to Natural Gas and Residuum as Refinery Fuel Sources........ 15

3.1 Conservation ........................................... 16



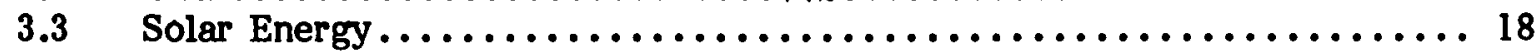

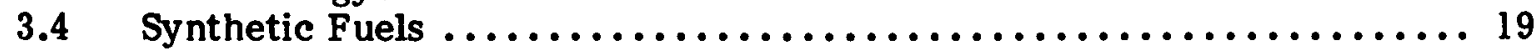

4.0 Conclusions $\ldots \ldots \ldots \ldots \ldots \ldots \ldots \ldots \ldots \ldots \ldots \ldots \ldots \ldots \ldots \ldots \ldots \ldots \ldots \ldots \ldots$




THIS PAGE

WAS INTENTIONALLY

LEFT BLANK 


\section{LIST OF FIGURES}

$1-1 \quad$ Refinery Flow Diag ram $\ldots \ldots \ldots \ldots \ldots \ldots \ldots \ldots \ldots \ldots \ldots \ldots \ldots \ldots \ldots \ldots \ldots \ldots$

2-1 Catalytic Reforming $\ldots \ldots \ldots \ldots \ldots \ldots \ldots \ldots \ldots \ldots \ldots \ldots \ldots \ldots \ldots \ldots$

LST OF TABLES

1-1 Refinery Energy Sources $\ldots \ldots \ldots \ldots \ldots \ldots \ldots \ldots \ldots \ldots \ldots \ldots \ldots \ldots \ldots \ldots \ldots \ldots$

1-2 The InterTechnology Corporation (1977): Process Heat Requirements for the Oil Refining Industry $\ldots \ldots \ldots \ldots \ldots \ldots \ldots \ldots \ldots \ldots \ldots \ldots \ldots \ldots \ldots \ldots$

1-3. Battelle (1977): Process Heat Requirements for the Oil Refining

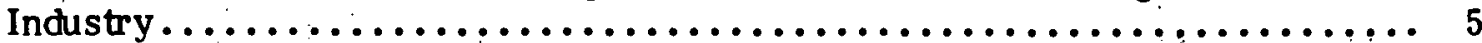

2-1 Crude Distillation Process Heat Requirements $\ldots \ldots \ldots \ldots \ldots \ldots \ldots \ldots \ldots \ldots$

2-2 Vacuum Distillation Process Heat Requirements ................. 8

2-3 Catalytic Reforming Process Heat Requirements ................. 10

2-4 Catalytic Cracking Process Heat Requirements $\ldots \ldots \ldots \ldots \ldots \ldots \ldots \ldots \ldots \ldots$

2-5 Hydrotreating and Hydrorefining Process Heat Requirements........... 12

2-6 Comparison of Oil Refinery Process Heat Requirements ............. 13

2-7 Variation of Process Heat Requirement with Temperature $\ldots \ldots \ldots \ldots \ldots \ldots$

3-1 Solar System Parameters ................................ 19 


\section{SECTION 1.0}

\section{INTRODUCTION}

In 1976 the U.S. gross energy consumption was 74.0 quads $^{1}$ (American Petroleum Institute 1977). This represented $30 \%$ of the world's energy consumption. Of the U.S. gross consumption, $18.6 \%$ of the energy was derived from coal, $47.2 \%$ from petroleum, $27.3 \%$ from natural gas, $4.1 \%$ from hydroelectric power, and $2.7 \%$ from nuclear energy. The energy was used in the following sectors: household and commercial $19.8 \%$, industrial $24.9 \%$, transportation $26.1 \%$, and electrical generation $28.9 \%$. On the basis of net energy consumption (i.e., energy that goes into the final consuming sector) totaling 59.6 quads, the breakdown was household and commercial $31.6 \%$, industrial $35.6 \%$, and transportation $32.4 \%$. Industry, as the largest energy-consuming sector, derived $18 \%$ of its energy from coal, 29.1\% from petroleum, 39.5\% from natural gas, and $13.2 \%$ from electricity. During 1976 , the U.S. consumption of refined petroleum products averaged 17,461 thousand barrels per day (MBPD). In 1974, consumption averaged 16,652 MBPD, and 12,133 MBPD (American Petroleum Institute 1977) of crude petroleum were refined domestically. The difference in the two figures was accounted for by volume processing gains and product imports.

Despite great increases in conversion ${ }^{2}$ levels, the use of more efficient catalytic processes in the petroleum refining industry has allowed energy consumption per unit of crude processed to remain approximately constant (Gordian Associates 1976, p. 27). At $632,000 \mathrm{Btu} / \mathrm{bbl}$ of charge, the domestic oil industry consumed 2.80 quads in 1974. This was equivalent to $11 \%$ of the energy content of the crude ( 1.3 million BPD of crude equivalent), or $3.8 \%$ of U.S. gross energy consumption.

Figure 1-1 illustrates a refinery flow diagram (Gary and Handwerk 1975). The source of refinery energy is shown in Table 1-1 (Solar Thermal Test Facilities Users Association 1978 , p. 274). The U.S. industry is unique in the world in that there is a significant consumption of natural gas. However, natural gas consumption is declining due to reduced availability, and it is being replaced with residual fuel oil. Electricity consumption is increasing as refineries switch from steam to more economical electric drives. The consumption of distillate and LPG as fuel is small, and is a function of the pricing structure relative to residual fuel oil and of the local storage situation. Natural gas, comprising about $30 \%$ of refinery fuel, is the only significant fuel derived from outside sources. Internally, the major part of the fuel requirements come from refinery fuel gas and coke. These are produced as by-products of the refinery processes and often are only suitable for consumption within the plant. In other instances, however, by-products such as hydrogen can be extremely valuable as feedstocks to refinery petrochemical processes; pipeline-quality gases can be sold advantageously to utilities through peaksharing arrangements.

${ }^{1}$ A quadrillion Btu $=10^{15} \mathrm{Btu}$

$=500,000 \mathrm{BPD}$ of petroleum for a year

$=40$ million tons of bituminous coal

$=10^{12}$ (one trillion) cubic feet of natural gas

$=100$ trillion $\mathrm{kWh}$ of electricity (based on $10,000 \mathrm{Btu} / \mathrm{kWh}$ heat rate).

${ }^{2}$ Conversion is the chemical change of one material into another through a chemical process. 
Typical

Refinery Products

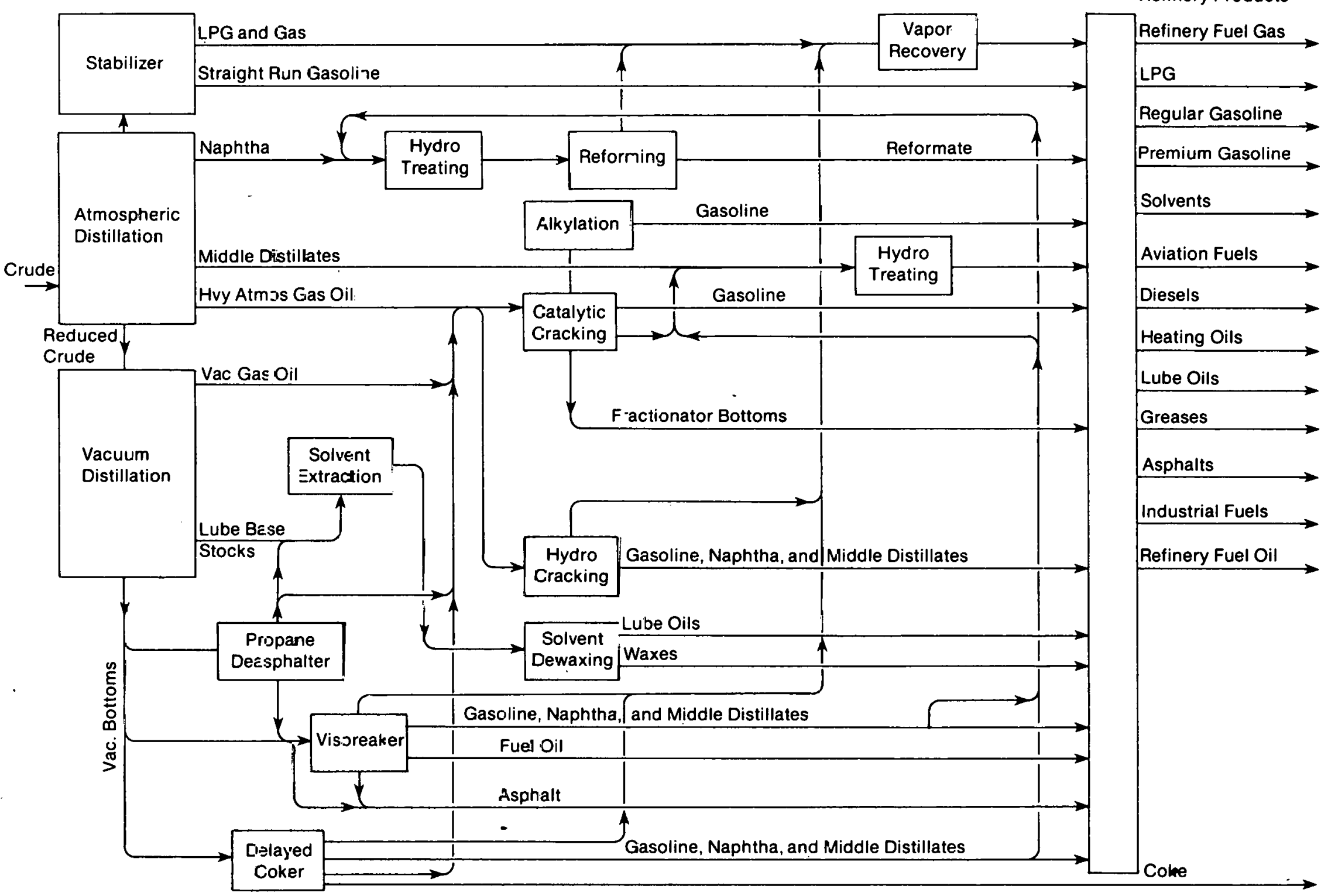

Figure 1-1. Refinery Flow Diagram 
Table 1-1. REFINERY ENERGY SOURCES (\%)

\begin{tabular}{lrr}
\hline & 1972 & 1977 \\
\hline Crude & 0.1 & 0.1 \\
Distillate & 0.5 & 0.9 \\
Residual & 8.6 & 10.1 \\
LPG & 1.4 & 0.9 \\
Natural Gas & 31.4 & 24.9 \\
Refinery Gas & 35.5 & 39.7 \\
Coke & 14.6 & 14.2 \\
Coal & 0.1 & 0.1 \\
Purchased Steam & 1.1 & 1.3 \\
Purchased Electricity & 6.7 & 7.8 \\
\hline
\end{tabular}

The consumption of liquid fuels, amounting to about $12 \%$ of energy requirements, represents a loss of liquid products. Presently, the market for residuum or vacuum bottoms, of ten high in sulfur content, is limited. Consequently, residuum is regarded as an economical and convenient source of refinery fuel. However, "bottom of the barrel" processing technology is advancing rapidly. A particular stimulus has derived from the supplies of heavier crude oils, which increasingly are entering world markets. Such crudes contain smaller fractions of lighter, more valuable components. Two basic technologies are being extensively researched to upgrade the heaviest fractions of these crudes. Thermal or catalytic cracking technologies liberate large quantities of byproduct gases . Hydrocracking technologies produce greater yields of valuable petroleum liquids and less by-product gas. In this latter case, the value of residuum could increase, leading to efforts to obtain more economical fuel alternatives. Thus, the mix of developing technologies adopted by refiners, by influencing the quantity of refinery gas and coke available, will effect the quantities of natural gas and residuum consumed directly as fuel. Currently, natural gas and residuum supply a little less than $40 \%$ of the energy requirements of a refinery. This represents the potential market for alternative fuel supplies.

The desire to reduce the consumption of residuum as fuel (by the widespread installation of hydrocracking technology, for instance) could be confounded if refiners were denied supplies of natural gas. Such circumstances could greatly intensify the search for al ternative sources of energy.

Apart from electrical power needs, almost all refinery energy is consumed for direct process heating or for the production of steam. The consumption of steam varies greatly from refinery to refinery (Battelle Columbus Laboratories 1977, p. 405). Much of a refinery's steam is derived by means of heat recovery from the various refinery processes. Generally this is through the use of economizcrs in process heaters. Another major source of steam in a refinery is the Fluid Catalytic Cracking Unit (FCCU). In this case, steam is produced both by burning off-gases in a carbon monoxide (CO) boiler, and by cooling the reactor products in the main column bottoms. Battelle $(1977$, p. 441$)$ quotes refinery steam use as 30 to 100 pounds per barrel of crude processed. For 1974, this would give a range of 159 to 531 trillion Btu/yr. Fuel used directly in steam production is likely to decline because of the switch to electric drives, and because more steam will be produced in process units as part of heat recovery systems. Using the above figures, 
after subtracting $\mathbf{8 . 5 \%}$ as the contribution from electricity and purchased steam, gives an estimated process heat requirement for 1974 of 2.0 to 2.4 quads.

Two major reports, InterTechnology Corporation (1977) and Battelle (1977), have documented the industrial process heat requirements of major energy-consuming industries. A summary of the ITC oil refining industry data is shown in Table 1-2. The base year is 1974, which was also used as the basis for this SERI report, in order to allow direct comparison with the ITC data. Table 1-3 illustrates the Battelle data summary. Capacity data in the Battelle report is based on the Oil and Gas Journal (OGJ) Annual Refinery Survey (Cantrell 1976) although there are some inconsistencies. For this SERI study, total crude refining capacity for 1974 is based upon the Bureau of Mines data (American Petroleum Institute 1977). It is assumed that such data, gathered over an entire year, are more reliable than the OGJ data showing capacities on a particular date. However, throughput for various units is based upon data presented in OGJ (Cantrell 1975).

Table 1-2. THE INTERTECHNOLOGY CORPORATION (1977): PROCESS HEAT REQUIREMENTS FOR THE OL REFINIHG DIDISTRY

\begin{tabular}{lcc}
\hline \multicolumn{1}{c}{ Process } & $\begin{array}{c}\text { Temperature } \\
\text { Requirement } \\
(\mathrm{F})\end{array}$ & $\begin{array}{c}\text { Process Heat } \\
\left(10^{12} \text { Btu/year }\right)\end{array}$ \\
\hline Crude Distillation & 650 & 275 \\
Vacuum Distillation & $440-800$ & 183 \\
Catalytic Reforming & 925 & 498 \\
Catalytic Cracking & 1125 & 447 \\
Catalytic Hydrotreating & & \\
and Hydrorefining & 700 & 176 \\
Thermal Operations & $555-1010$ & 154 \\
Delayed Coking & 900 & 225 \\
Hydrmiracking & $515-810$ & 91 \\
Alkylation & $45-340$ & 59 \\
Hydrogen & 1600 & 124 \\
Olefins and Aromatics & 1200 & 124 \\
Lubricants & Not reporter & 25 \\
Asphalt & NR & 96 \\
Butadiene & $250-350$ & 60 \\
Total & & 2537 \\
\hline
\end{tabular}


Table 1-3. BATTELLE (1977): PROCESS HEAT REQUIREMENTS FOR THE OI REFINING INDUSTRY

\begin{tabular}{|c|c|c|c|c|}
\hline Process & $\begin{array}{l}\text { Temperature } \\
\text { Requirement } \\
(\mathrm{F})\end{array}$ & $\begin{array}{c}\text { Fired Heat } \\
(\mathrm{Btu} / \mathrm{bbl})\end{array}$ & $\begin{array}{l}\text { Quantity } \\
\text { Processed } \\
\left(10^{6} \text { BPD }\right)\end{array}$ & $\begin{array}{l}\text { Process Heat } \\
\left(10^{12} \mathrm{Btu} / \text { year }\right)\end{array}$ \\
\hline \multicolumn{5}{|l|}{ Crude } \\
\hline Distillation & 650 & 70,000 & 14.8 & 380 \\
\hline \multicolumn{5}{|l|}{ Vacuum } \\
\hline Distillation & 780 & 30,000 & 5.4 & 59 \\
\hline \multicolumn{5}{|l|}{ Catalytic } \\
\hline Reforming & 1000 & 300,000 & 3.4 & 374 \\
\hline \multicolumn{5}{|c|}{ Catalytic Cracking } \\
\hline Fluid Bed & 950,1200 & 70,000 & 11.5 & 293 \\
\hline Moving Bed & 920 & 300,000 & 1.5 & 162 \\
\hline \multicolumn{5}{|c|}{ Hydrotreating and } \\
\hline Hydrorefining & 800 & 70,000 & 4.9 & 126 \\
\hline Visbreaking & 975 & 260,000 & 1.4 & 132 \\
\hline Coking & 1050 & 350,000 & 3.0 & 381 \\
\hline Hydrocracking & 800 & 200,000 & 8.5 & 624 \\
\hline Alkylation & 300 & $\begin{array}{l}\text { Steam } \\
\text { Heated }\end{array}$ & & \\
\hline Hydrogen & 1000 & 100,000 & NA & NA \\
\hline Lubricants & Low & 0 & 0.22 & Steam \\
\hline Asphalt & 500 & 200,000 & 0.71 & 53 \\
\hline Isomerization & 500 & 30,000 & 0.47 & 3.5 \\
\hline Total & & & & 2587.5 \\
\hline
\end{tabular}

Surveys such as the ITC report allow process heat usage to be classified as a function of temperature and industry. Thus, $18 \%$ of total process heat (ITC 1977) is estimated to be consumed in the temperature range $550-1100^{\circ} \mathrm{F}$. Ketels and Reeve (1979) have further refined ITC data to show that $98.5 \%$ of the energy consumed as process heat in the above temperature range is consumed by the petroleum refining industry. Thus, the characteristics of energy use in the temperature range $550-1100^{\circ} \mathrm{F}$ can be determined almost entirely by an investigation of the petroleum refining industry. The analysis that follows compares energy consumption in major refining processes as reported in the Battelle and ITC studies, and as derived independently here. 


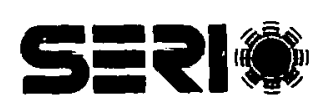




\section{SECTION 2.0}

\section{ENBRGY CONSUMPTION IN MAJOR REFINERY PROCESSES}

\subsection{CRUDE DISTH.LATION}

Crude distillation is a separation process whereby crude petroleum is fractionated into various constituents on the basis of differences in boiling points. From the top of the column, a mixture of light gases (methane and ethane), LPG (propane and butane), and a light gasoline fraction is evolved. Heavier sidestream products are taken off at various points in the column. Descending the column, these are naphtha (used as reformer feed for upgrading into high-octane gasoline), kerosine (that can be upgraded into jet fuel), diesel (that is essentially the same as domestic fuel oil), and atmospheric gas oil (AGO). Reduced crude (RCD) is taken from the bottom of the crude column as feed to a vacuum unit. Kerosine and diesel fractions are known collectively as middle distillates.

In order to remove heat from the crude column and to improve the separation process, circulating sidestreams are contacted with the incoming crude oil in a series of heat exchangers. Heat is also exchanged with products going to storage. Desalters are located at a point where the crude reaches approximately $250^{\circ} \mathrm{F}$. Heat exchange raises the crude temperature to $400-500^{\circ} \mathrm{F}$, at which point it enters the crude heater. Here process heat is supplied in a combination oil-and gas-fired furnace to raise the crude to $640-680^{\circ} \mathrm{F}$ for de livery to the tower. Table 2-1 shows a comparison of ITC and Bat telle data with other data derived from industrial sources.

Table 2-1. CRUDE DISTILATION PROCESS HEAT REQUIREMENTS

\begin{tabular}{lccc}
\hline & ITC & Battelle & SERI \\
\hline Temperature Requirement $\left(^{\circ} \mathrm{F}\right)$ & 650 & 650 & 650 \\
Crude Throughput $\left(10^{6} \mathrm{BPD}\right)$ & 13.748 & 14.845 & 12.133 \\
Specific Energy $\left(\mathrm{Btu}^{\mathrm{t}} \mathrm{bbl}\right)$ & 54,800 & 70,000 & 68,000 \\
Total Energy $\left(10^{\mathrm{Btu} / \mathrm{yr})}\right.$ & 275 & 380 & 301 \\
\hline
\end{tabular}

Table 1-4 shows good agreement between the data. In some refinery configurations, the gasoline fraction from the top of the crude column is stabilized to remove high vapor: pressure, low boiling point components before being sent to storage. These components (butane and lighter materials) could cause dangerous conditions in the storage tanks, and they would cause an automobile engine to vapor-lock. Stabilization is accomplished in $a$ distillation column at a temperature of about $360^{\circ} \mathrm{F}$. Process heat requirements are approximately $47,000 \mathrm{Btu} / \mathrm{bbl}$, but heat is generally supplied by circulating sidestreams through a reboiler exchanger.

\subsection{VACUUM DISTILLATION}

Reduced crude from the bottom of the crude column at about $620^{\circ} \mathrm{F}$ is pumped directly to the vacuum unit heater, where the temperature is raised to between $700^{\circ}$ and $790^{\circ} \mathrm{F}$. Distilling the RCD under vacuum allows the separation of its components while 
preventing their thermal decomposition. Products from the vacuum column are vacuum gas oils (VGO) used as feed to cataly tic cracking, hydrocracking or desulfurization units, lube oils, and vacuum bottoms or residuum. This latter can be blended to fuel oil, used directly or after further processing as asphalt, or can form feed to a visbreaker or coking unit. Table 2-2 shows the comparison of data sources.

Table 2-2. VACUUM DISTHLATION PROCESS HEAT REQUIREMENTS

\begin{tabular}{lccc}
\hline & ITC & Battelle & SERI \\
\hline Temperature Requirement $\left({ }^{\circ} \mathrm{F}\right)$ & $440-800$ & 780 & 755 \\
Throughput $\left(10^{6}\right.$ BPD) & 13.3 & 5.4 & 4.37 \\
Specific Energy $(\mathrm{Btu} / \mathrm{bbl})$ & 37,650 & 30,000 & 64,000 \\
''otal Energy $\left(10^{12} \mathrm{Btu} / \mathrm{yr}\right)$ & 183 & 59 & 102 \\
\hline
\end{tabular}

Variations in specific heat requirements probably reflect different heat exchanger configurations used to supply heat to other units There is some discrepancy in the ITC throughput figure. At a throughput of $5 \times 10^{6} \mathrm{BPD}$, the energy requirement would be $69 \times 10^{12} \mathrm{Btu} / \mathrm{yr}$.

\subsection{GAS FRACTIONATION}

The overhead from a refinery crude column is generally piped to a gas fractionation unit. The liquid gasoline fraction is stabilized and the butane and lighter components separated into refinery fuel gas, propane, and butane. Typically, $20 \%$ of the incoming crude is taken overhead. A reboiler temperature of about $360^{\circ} \mathrm{F}$ is required to stabilize the gas? line, and $225^{\circ} \mathrm{F}$ is required to split propane and butane. It is generally more economical to supply heat for such distillations by cuoling process strcams, although the lower temperature requirement can be sulisfied using condensing ste.nm. An alternative stabilizer column heat source is a fired heater or a hot oil loop. One plant, for example, requires $96,000 \mathrm{Btu} / \mathrm{bbl}$ of thermal energy for gas fractionation. Approximately half of this figure was supplied by process heat exchange. Extending this requirement to the entire industry results in a fuel requirement of $42.5 \times 10^{12} \mathrm{Btu} / \mathrm{yr}$ for 1974 . ITC does not document a process heat requirement for gas processing. Battelle assumes all the requirement is met using steam. At $1200 \mathrm{Btu} / \mathrm{lb}$ average enthalpy of steam Battelle (1977, p. 441) estimates the energy used in gas processing in 1974 was $114 \times 10^{12} \mathrm{Btu} / \mathrm{yr}$. Considering that this was the total refinery requirement, it is not out of line with the total derived from the industrial example quoted above.

It is significant to note the high heat requirements at low heat quality. This arises because the difficulty of separation necessitates high column reflux rates. Also at the low temperatures involved, there is little opportunity for low-temperature heat utilization through cassading heat exchange.

\subsection{CATAL YTIC REFORMING}

This is a process that upgrades the octane of straight-run naphtha. A diagram of the process is shown in Fig. 2-1. Hydrogen, fuel gas, and LPG are produced as by-products of 


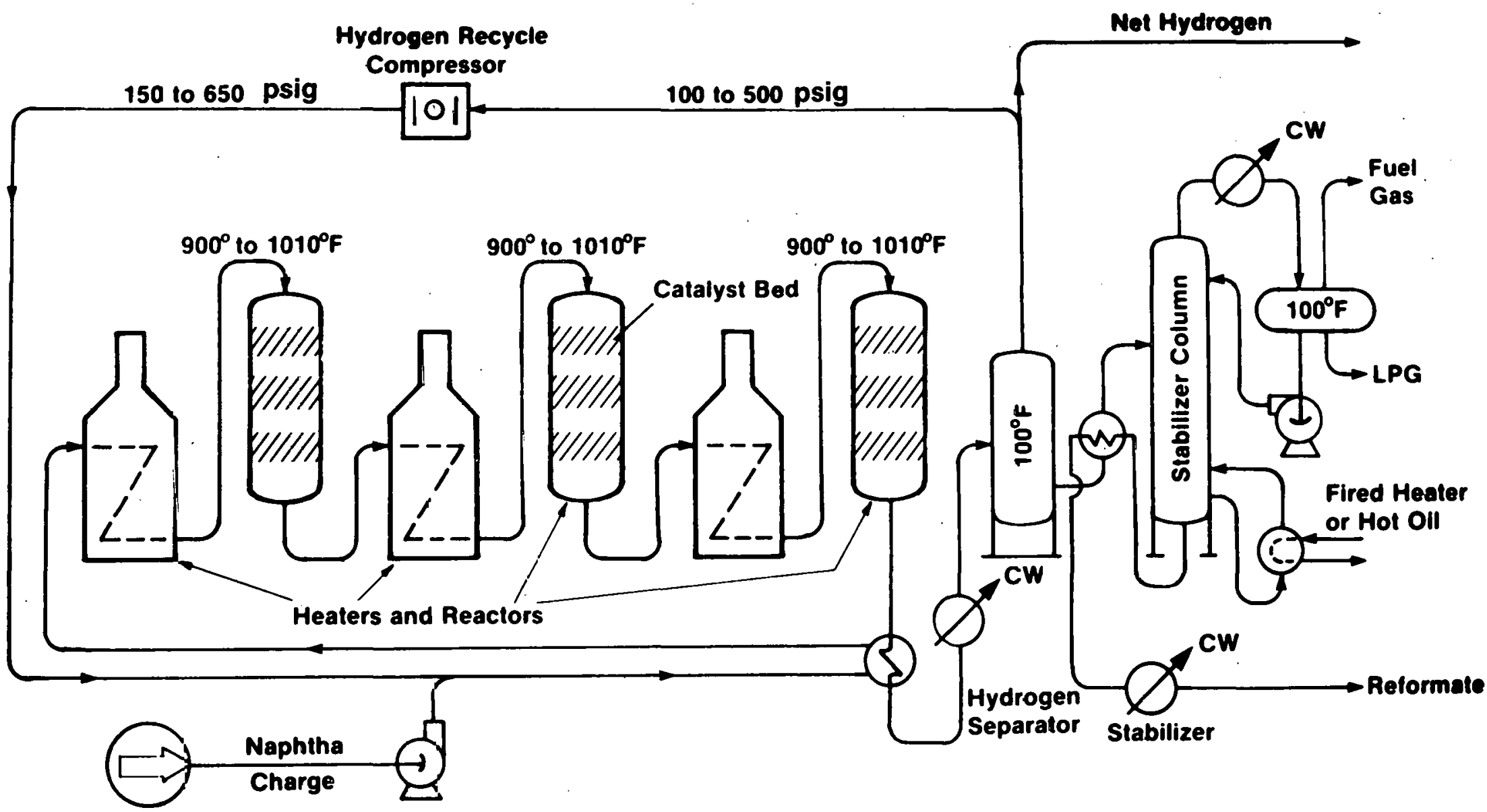

Figure 2-1. Catalytic Reforming 
the process. The incoming naphtha is mixed with a recycle hydrogen stream, heat exchanged and heated to from $900^{\circ}$ to $1010^{\circ} \mathrm{F}$ before entering the first of three or four reactors. The reaction is highly endothermic; thus, to maintain the reaction temperature, the effluent from reactor one is reheated before entering reactor two. This is also true for reactors three and four.

After heat exchange and cooling, the final reactor effluent liquid stream is stabilized. For newer units, a fired reboiler is usually employed, consuming about 35,000 Btu/bbl at a delivery temperature of about $520^{\circ} \mathrm{F}$. Process heat requirements are shown in Table 2-3.

Table 2-3. CATALYTIC REPORMING PROCESS HEAT REQUIREMENTS

\begin{tabular}{lcccc}
\hline & & & \multicolumn{2}{c}{ SERI } \\
\cline { 4 - 5 } & ITC & Battelle & Reforming & Stabilization \\
\hline Temperature Requirements $(\mathrm{F})$ & 925 & 1000 & $900-1010$ & 520 \\
Throughput (10 $\mathrm{BPD})$ & 3.99 & 3.42 & 2.72 & 2.72 \\
Specific Energy (Btu/bbl) & 342,000 & 300,000 & 270,000 & 35,000 \\
Total Energy (10 $12 \mathrm{Btu} / \mathrm{yr})$ & 498 & 374 & 268 & 35 \\
\hline
\end{tabular}

The ITC report appears to overestimate reforming throughput.

An important observation regarding the reforming process is that it typically produces about 850 cubic feet of $480 \mathrm{Btu} / \mathrm{sef}$ heating value net off-gas per barrel processed. This is equivalent to $408,000 \mathrm{Btu} / \mathrm{bbl}$ of naphtha feed. The gas is approximately $70 \%$ hydrogen, which is a valuable commodity if the refinery operates hydrocracker or major desulfurizing units. If it cannot be used as a feedstock, the gas is added to the refinery fuel gas supply. More fuel gas, as well us LPG, is producod from the stabilizer overhead. Again, waste heat boilers on the charge heaters recover energy from the flue gases. Thus, though the reforming process is highly energy intensive, it can be a net contributor to the refinery fuel and steam supply.

\subsection{CATALYTIC CRACKING}

This process converts atmospheric and vacuum gas oils to primarily gasoline. By-products are olefinio gases used as feed to gasoline polymerization and alkylation units, and aromatic cycle oils that form constltuents of diesel fuel or heavy fucl oils. Abnut $90 \%$ of the installed catalytic cracking capacity is made up of the more-efficient fluidized-bed (FCC) process. The remaining capacity employs the moving-bed process.

A modern FCC unit would take hot feed at about $360^{\circ} \mathrm{F}$ directly from the crude and vacuum units. This feed is contacted with hot recirculating calalyst. As a consequence of the cracking reaction, besides producing the desired products, approximately $5 \%$ of the feed is deposited as carbon on the catalyst. This carbon inhibits the cataly tic activity of the catalyst, and, therefore, the catalyst is transferred to a regenerator. Here, air fluidizes the catalyst and burns off the carbon. A great deal of energy is evolved in this process, which is carried out, depending on the unit, at between $1100^{\circ}$ and $1300^{\circ} \mathrm{F}$. Some 
of the energy is transferred by the catalyst to the incoming oil. The regenerator off-gas can be directed to a carbon monoxide (CO) boiler, where the carbon monoxide is reacted with air to generate steam. Often such a boiler is the largest steam producer in a refinery. Alternatively, the CO can be completely burned in the regenerator, and the hot off-gases passed through a turbine, which is used to drive the main air blower. Additional energy is recovered from the process by the generation of steam in the main column bottoms. Older units do consume energy in preheating the feed to $600^{\circ} \mathrm{F}-700^{\circ} \mathrm{F}$ before entering the reactor riser. Values of 70,000 and $300,000 \mathrm{Btu} / \mathrm{bbl}$ (Battelle 1977, p. 432) are used as the requirements for the FCC and moving-bed processes, respectively, to produce the data shown in Table 2-4.

Table 2-4. CATALYTIC CRACKING PROCESS HEAT REQUIREMENTS

\begin{tabular}{lllll}
\hline & ITC & & Battelle & SERI \\
\hline Temperature Requirement $\left(^{\circ} \mathrm{F}\right)$ & 1125 & FCC & $950,1200^{\mathrm{a}}$ & $\mathbf{6 0 0 - 7 0 0}$ \\
& & Moving Bed & 920 & $600-700$ \\
Throughput $\left(10^{6} \mathrm{BPD}\right)$ & Not & FCC & 11.5 & 3.3 \\
& Reported & Moving Bed & 1.48 & 0.37 \\
Specific Energy (Btu/bbl) & NR & FCC & 70,000 & $150,000^{\mathrm{b}}$ \\
Total Energy (10 & & Moving Bed & 300,000 & 300,000 \\
& & FCC & 293 & $181^{\mathrm{c}}$ \\
Total & 447 & Moving Bed & 162 & 41 \\
\hline
\end{tabular}

$a_{\text {Regenerator off-gas temperature. }}$

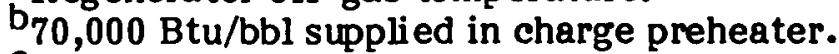

$c_{85}$ trillion $\mathrm{Btu} /$ year as direct-fired process heat.

The energy produced in the regenerator can be regarded as a heat input to the process. Assuming $5 \%$ of the feed is deposited on the catalyst, and that the heat of combustion of the feed is $5.3 \times 10^{6} \mathrm{Btu} / \mathrm{bbl}$, then the $1974 \mathrm{FCC}$ regenerator thermal output was 319 trillion Btu. Approximately $30 \%$ of this total cean be rogarded as a proiess heat requirement in bringing up the feed temperature from about $650^{\circ}$ to $950^{\circ} \mathrm{F}$. The remainder is used in steam or power production.

The throughput figures quoted from the Battelle report, Table 2-2, disagree with the figures in the body of that report (p. 430) which document throughput as 4.41 MMBPD. Using these latter, more-realistic figures, the Battelle process heat requirement is only 155 trillion Btu/year. Both reports quote incorrect temperature requirements. For process heat considerations, the charge heater delivery temperature is the relevant parameter. The actual temperatures of the reactor and the regenerator are not important. For a throughput of 4.0 MMBPD, the ITC data suggest a process heat requirement of over $300,000 \mathrm{Btu} / \mathrm{bbl}$. This is an excessive process heat requirement, as it approximates heat released in the regenerator plus energy supplied in the charge preheater. 


\subsection{PROCESSING CATALYTIC CRACKING OPF-GASES}

Approximately $15 \%$ of a catalytic cracker feed is converted into olefinic gases, which pass overhead from the main column. These are processed in a unit similar to a crude column gas processing unit. The $\mathrm{C}_{3} / \mathrm{C}_{4}$ fraction is used as feed to an alkylation or polymerization unit, where the olefins and iso-paraffins are combined to form high-octane gasoline. Again, temperature requirements are moderate, being $400^{\circ} \mathrm{F}$ and below. ITC (1977, p. 1718) quotes a specific process heat requirement of $115,920 \mathrm{Btu} / \mathrm{bbl}$. Thus, in 1974 the processing of catalytic cracking off-gases consumed 23.2 trillion Btu of fuel. Added to crude column gas processing heat requirements of 85 trillion Btu/year, the estimated fuel consumption of the two largest refinery gas sources for gas processing was 108 trillion Btu/year. Battelle assumes all gas processing heat requirements are met using steam, and the total refinery figure amounts to 114 trillion Btu/year, showing an agreement in the approximate size of the requirement for gas processing. It is assumed for this study that half of the catalytic eracking gas processing heating requirements, i.e., 11.6 trillion Btu/year, are satisfied using fired heater's.

\subsection{CATALYTIC HYDROTREATING AND HYDROREFINING}

The main process in this category is the treatment of naphtha prior to processing in a reformer. Reactor temperatures are between $600^{\circ}$ and $700^{\circ} \mathrm{F}$. Approximately half the process heat requirement is to the hydrogen sulfide stripper at $550^{\circ} \mathrm{F}$. Such heat is generally supplied from a fired heater. Table 2-5 shows a data comparison.

\section{Table 2-5. HYDROTREATING AND HYDROREFINING PROCESS HEAT REQUIREMENTS}

\begin{tabular}{|c|c|c|c|c|}
\hline & \multirow[b]{2}{*}{ ITC } & \multirow[b]{2}{*}{ Battelle } & \multicolumn{2}{|c|}{ SERI } \\
\hline & & & $\begin{array}{c}\text { Hyalro- } \\
\text { proceśsing }\end{array}$ & Distillation \\
\hline $\begin{array}{l}\text { Temperature Requirement }\left({ }^{\circ} \mathrm{F}\right) \\
\text { Throughput }\left(10^{6} \mathrm{BPD}\right) \\
\text { Specific Fnergy (Btu/bbl) } \\
\text { Total Energy }\left(10^{12} \mathrm{Btu} / \text { year }\right)\end{array}$ & $\begin{array}{l}700 \\
\mathrm{NR} \\
\mathrm{NR} \\
178\end{array}$ & $\begin{array}{c}800 \\
4.9 \\
70,000 \\
126\end{array}$ & $\begin{array}{c}700 \\
4.7 \\
35,000 \\
\text { 6n }\end{array}$ & $\begin{array}{c}550 \\
4.7 \\
35,000 \\
60\end{array}$ \\
\hline
\end{tabular}

\subsection{VISBRFAKING AND COKING}

In 1974, total thermal processing capacity was 1.16 MMBPD (Cantrell 1975). Even if process heat requirements were as high as the value of $350,000 \mathrm{Btu} / \mathrm{bbl}$ quoted by Battelle, this would give total usage of only 128 trillion Btu/year. ITC quotes a requirement of 379 trillion Btu/year. Battelle documents thermal capacity as 4.4 MMBPD. These latter two values appear unrealistic. 


\subsection{HYDROCRACKING}

There is an error of a factor of 10 in the Battelle hydrocracking throughput. A more-realistic value is $0.32 \times 10^{9} \mathrm{bbl} /$ year (870 MBPD) giving an energy usage of 62 trillion Btu/year, based on a specific energy consumption of $200,000 \mathrm{Btu} / \mathrm{bbl}$.

\subsection{SUMMARY}

The processes discussed above are the main energy consumers in a refinery. A comparison of data sources is shown in Table 2-6. Certain obvious errors in the ITC and Battelle reports have been corrected. For the purpose of this study, data for processes not discussed above have been taken directly from either of the two reports. While the total is somewhat less than the lowest estimate of 2.0 quads previously derived, it is obvious that not all refinery processes have been included, and that it is difficult to accurately estimate the average energy consumption for a particular process. The ITC report does not detail calculations, so it is difficult to explain the high requirements for reforming, cracking, etc., that tend to inflate the total. Also, it includes processes not covered in the Battelle report. The Battelle study shows greater reliance on the use of steam as a process heating medium.

Table 2-6. COMPARISON OF OIL REPINERY PROCESS HEAT REQUIREMENTS

\begin{tabular}{|c|c|c|c|c|}
\hline \multirow{2}{*}{ Process } & \multicolumn{3}{|c|}{$\begin{array}{l}\text { Process Heat } \\
\left(10^{12} \mathrm{Btu} / \text { year }\right)\end{array}$} & \multirow{2}{*}{$\begin{array}{c}\text { Temperature } \\
\text { Requirement } \\
\text { ( } \mathrm{F})\end{array}$} \\
\hline & ITC & Battelle & SERI & \\
\hline Crude Distillation & 275 & 380 & 301 & 650 \\
\hline Vacuum Distillation & $59^{a}$ & 59 & 102 & 755 \\
\hline Gas Fractionation & NR & Steam & 54 & 360 \\
\hline Cataly tic Reforming & 498 & 374 & $\begin{array}{r}268 \\
35\end{array}$ & $\begin{array}{l}900-1010 \\
520\end{array}$ \\
\hline Catalytic Cracking & 447 & $155^{\mathrm{a}}$ & $181^{h}$ & $600-700$ \\
\hline \multicolumn{5}{|l|}{ Hydrotreating and } \\
\hline Hydrorefining. & 176 & 126 & $\begin{array}{l}60 \\
60\end{array}$ & $\begin{array}{r}700 \\
550\end{array}$ \\
\hline Visbreaking and Coking & 379 & 515 & 128 & $900-1050$ \\
\hline Hydrocracking & 91 & $62^{\mathrm{a}}$ & 50 & 800 \\
\hline Alkylation & 59 & Steam & $(59)$ & $45-340$ \\
\hline Hydrogen & 124 & NR & $(124)$ & 1600 \\
\hline Olefins and Aromaties & 124 & NR & $(124)$ & 1200 \\
\hline Lubricants & 25 & Steam & $(25)$ & Low \\
\hline Asphalt & 96 & 53 & $(53)$ & 500 \\
\hline Isomerization & NR & 3.5 & $(3.5)$ & 500 \\
\hline Butadiene & 60 & NR & $(60)$ & $250-350$ \\
\hline Total & 2413 & 1728 & 1688 & \\
\hline
\end{tabular}

a Corrected

$\mathrm{b}_{85}$ trillion Btu as direct fired heat.

( ) Data from ITC or Battelle 
The main conclusion that can be drawn from this survey of refinery processes, regardless of the actual quantities of energy involved, is that the Battelle and ITC studies overestimate total process heat requirements, and the temperature at which this heat is delivered. It is obviously misleading to assign a single temperature to an industrial process without a thorough investigation of the process. Table 2-7 is a comparison of process heat requirements as a function of temperature. This report estimates temperature requirem ents in the $550^{\circ}$ to $1100^{\circ} \mathrm{F}$ range much lower than estimates by ITC and Battelle. Our calculations indicate that $22 \%$ of refinery process heat is delivered at a temperature less than $550^{\circ} \mathrm{F}$, with another $63 \%$ delivered between $550^{\circ}$ and $1100^{\circ} \mathrm{F}$. These figures are consistent with the work of Nelson (Thermo Electron Corp. 1976) who estimates that, of the energy supplied for nonsteam heating, $18 \%$ is delivered to processes operating below $600^{\circ} \mathrm{F}, 65 \%$ is delivered to processes operating between $600^{\circ}$ and $1000^{\circ} \mathrm{F}$, and $17 \%$ to processes operating above $1000^{\circ} \mathrm{F}$.

Table 2-7. VARIATION OF PROCESS HBAT REQUIREMENTS WITH TEMPERATURE (\%)

\begin{tabular}{llcl}
\hline $\begin{array}{c}\text { Temperature } \\
\text { Range } \\
\text { ( } \mathrm{F})\end{array}$ & ITC & Battelle & SERI \\
\hline Below 550 & 9.5 & 2.2 & 22 \\
$550-1100$ & 80.5 & 97.8 & 62.5 \\
Above 1100 & 10 & 0 & 15.5 \\
\hline
\end{tabular}




\section{SECTION 3.0}

\section{ALTERNATIVES TO NATURAL GAS AND RESIDUUM AS REFINERY FUEL SOURCES}

The potential for displacement of natural gas and fuel oil in a refinery amounts to somewhat less than $40 \%$ of total energy usage. Assuming future reductions in natural gas supplies and increases in crude costs, circumstances could arise producing a real incentive to shift to economical alternatives to residuum and natural gas. Before considering these alternatives, some clarification of the refinery operating environment is required.

Typically, a refinery will occupy a square mile or two. However, most of this area is occupied by the tank farm or is set aside as a buffer zone or for future expansion. Oil processing is carried out in a very confined, crowded space. By locating all the processing units close together, a great many economies are realized. Piping runs among and between units are greatly minimized. Fluids can be easily transported from one unit to another, with minimum pressure and temperature losses. Centralized control rooms can be used, minimizing manpower requirements. Personnel have smaller distances to travel to deal with routine work-and operating problems. The great disadvantage of this practice is one of safety: an emergency in one unit can easily spread to adjacent units.

Within this crowded processing area are many fired heaters ranging in output from about 10 to 400 million Btu/h. The temperature of the process fluid passing through the heater tubes is crucial to the design of the heater. At temperatures above about $700^{\circ} \mathrm{F}$, organic compounds tend to thermally crack. Such a process will deposit coke on the tube internals, restricting heat transfer. A reduction in heat transfer can cause "hot spot" formation on the tubes. If reduced heat transfer is prolonged, tube failure and a consequent fire or explosion can result. Thus, in processes such as crude and vacuum distillation, coking, and visbreaking (where temperatures higher than $700^{\circ} \mathrm{F}$ are required), coking is minimized by rapidly heating the process fluid at high rates of heat transfer and then transferring the fluid to downstream equipment immediately adjacent to the heater outlet. Often, steam is injected into the heater coils to increase fluid velocity and reduce contact time.

Thermal cracking is inhibited by hydrogen. Consequently, it is not a problem in such processes as reforming, hydrotreating, hydrorefining, and hydrocracking, where temperatures far in excess of $700^{\circ} \mathrm{F}$ are used. However, large hydrogen/hydrocarbon ratios are required to reduce coke formation. This is achieved by recycling hydrogen through the unit. To prevent excessive compressor energy usage, and also for process reasons, it is necessary to minimize pressure drop through the recycle system. This can only be achieved by special design of the process equipment, including the heaters, and by minimizing piping runs between the equipment.

For most refining processes, temperature is the main operating variable. Pressures are not usually changed, and flow rates are adjusted as demanded within the limitations of the unit. Accurate, rapid temperature control necessitates minimum residence times, and hence close spacing between the herter and downstream equipment.

Characteristics of the two above types of processes (i.e., those involving and those not involving hydrogen) are high-temperature requirements, high heat-transfer rates, and closeness of process equipment. These characteristics are typical of the reforming unit previously shown in Fig. 2-1. Thus, there would appear to be little alternative to existing radiant-type heaters located in the processing area to satisfy heat requirements for these 
processes. Conceivably, the heat could be supplied through heat exchange. However, the mechanical requirements of a heat exchanger operating at such temperatures would be extremely rigorous. The exchanger would have to operate with the minimum of pressure drop and would have to allow accurate process temperature control. Also, a stable and safe heat transfer fluid would be required to supply the process heat.

The requirement for accurate temperature control has other ramifications. For instance, the heater outlet temperature of a reformer should be controlled within $1^{\circ} \mathrm{F}$. Such a requirement necessitates that constant firing rates be achieved via uniform fuel properties. An alternative to present liquid or gaseous fuels must conform to this criterion.

A third type of refinery process demands temperatures below thermal cracking temperatures and generally even below $550^{\circ} \mathrm{F}$. These are the reboiling of distillation columns for gas processing, reforming, hydrotreating, alkylation, etc., and for asphalt, lubricant, and butadiene manuf acture. Such temperatures can be achieved through heat exchange using commercially available equipment. Often, hot process streams are used as a heat source. Once this possibility is exhausted, an alternative to the use of individually fired heaters is to distribute a heat transfer fluid heated at a centralized location. This type of system is already in use at some refineries. While supplying heat through heat exchange gives less accurate control than using individually fired heaters, the temperature requirements for distillation are somewhat less exact than those required for catalytic processes.

Thus, natural gas and fuel oil comprise roughly $40 \%$ of the total energy supply of a refinery. This percentage could therefore be replaced by alternatives. However, technological constraints mean that such alternatives can vary little in properties from fuels presently used for processes above $700^{\circ} \mathrm{F}$. It is shown in the previous section that $22 \%$ of refinery process heat was consumed below $550^{\circ} \mathrm{F}$; up to a temperature of $700^{\circ} \mathrm{F}$ could account for perhaps one-quarter of process heat usage (0.8 quads in 1977). This is the potential market for fuel alternatives such as coal and solar energy. The nature of the demand for industrial process heat, (dominated by the oil refining industry in the range $550-1100^{\circ} \mathrm{F}$ ) is such that the market for process heat from alternative sources of fuel in the range $700-1100^{\circ} \mathrm{F}$ is almost nonexistent.

\subsection{CONSERVATION}

Conservation is an obvious alternative to the present importation of refinery fuels. A target of a 19\% reduction in energy consumption over the base of 1972 has been set for the oil refining industry by January 1, 1980 (Gordian Associates 1976, p. 4). This goal will be met and surpassed as energy custs rise. However, the hasis has changed significantly since 1972:--Environmental regulations, the increased demand for unleaded gasoline, and increased conversi on levels all require added energy inputs. These partially offset conservation measures and advances in technology. Thus, while the energy conservation potential is significant, the probable decrease in overall energy consumption per barrel of crude processed will be much less than a direct comparison with the 1972 base year would indicate.

A factor to consider in planning conservation measures concerns the resultant increase in the complexity of operations. A forced-draught heater with air-preheat is far more complex than the natural-draught alternative. The further integration of refinery units through the use of cascading heat exchange can cause operating instabilities, reduces 
operating flexibility, can reduce safety, and makes start-up much more difficult. While refinery personnel and modern control technology are well equipped to deal with such problems, these considerations do impose on the major concern of an industrial operation, i.e., maintaining production. Future major increases in the efficiency of energy utilization are likely to derive from breakthroughs in catalysis, advances in equipment technology (such as the use of heat pumps to heat distillation columns), and the replacem ent of old equipment with newer, more-efficient, larger units.

\subsection{COAI.}

The trend in the oil refining industry as natural gas supplies have been curtailed has been a shift from gas- to oil-burning facilities. The conversion is simple and cheap, requiring only the installation of soot blowers to maintain almost the same furnace efficiency. Residuum is the lowest-value component of crude oil; it is generally worth less than the crude from which it is processed. Even at a cost of $\$ 20$ per barrel, residuum delivers energy at about $\$ 3.20$ per million Btu. Thus, whereas oil refining consumes about $11 \%$ of the energy content of the incoming crude, energy costs represent only $6 \%$ of the product value (Mann and Heller, p. 26).

It is significant that refinery operators have made little attempt to install coal-burning facilities. Industry has found that the capital investment for a coal-burning facility can be up to eight times the cost of a similar facility burning oil or gas (Solar Thermal Test Facilities Users Association 1978, p. II-4). Coal usage requires transportation facilities and large areas of land for storage. Solids handling is inefficient compared to pumping oil. The coal must be crushed prior to buming, and provision must be made for ash removal and disposal. Coal, unlike oil or gas, is an extremely variable material. Process temperature control would be extremely difficult, and variations in flame height could cause impingement on heater tubes. Coal-burning facilities do not appear to be economical in sizes less than 100 million Btu/h (Chemical Engineering 1979, p. 71 ), and few heaters in a refinery are of this size. The technology of burning coal in a process heater is unknown, and there are no recorded installations (Mann and Heller, p. 33) Coal contains a great number of impurities, resulting in extremely corrosive flue gases. It is doubtful whether the alloys used for refinery heater piping or refractory linings can withstand such an environment. For instance, high chromium steel alloys, which are widely used in high-pressure hydrogen processes, are extremely susceptible to chloride attack. In addition, ash and slag deposition on furnace tubes could cause corrosive attack and temperature buildups.

These factors would tend to preclude the direct use of coal in the two types of high-temperature refinery processes mentioned previously, at least for the short term. In the long term, the widening differential between the cost of coal and fuel oil will lead to greater consideration of coal for use in process heaters. On the technical front, techniques of fluid-bed combustion are undergoing intense development. Such technology could overcome environmental and the above technical barriers to the use of coal. Coal could be used in the production of steam, where the technology is well known. The steam could be supplied as a by-product of a cogeneration facility used to produce electricity. On the other hand, the amount of fuel used in the direct production of steam for process heat is likely to decline as more waste heat boilers are installed on process heaters. Coal could be used to satisfy refinery low-temperature heat requirements by heating a heat transf er fluid at a remote location. Such a facility could be quite large and could justify the installation of flue gas treatment facilities. Refineries are often located in urban areas, where no decrease in air quality can be tolerated. Therefore, as with other 
industries, environmental problems are the major obstacle to the present use of coal as a fuel in the oil-refining industry.

In summary, coal could be used to satisfy refinery low-temperature requirements if problems of pollution, storage, and solids handling can be overcome. Such an application would necessitate the replacement of direct-fired heaters with heat exchangers supplying heat via a heat transfer fluid. In the long term, if technical and environmental problems can be resolved, coal could be used to fuel process heaters.

\subsection{SOLAR ENERGY}

Solar systems capable of delivering temperatures up to $350^{\circ} \mathrm{F}$ are already in commercial operation (Aerospace Corporation 1978, p. II-3). The parabolic trough collector is capable of producing temperatures up to $550^{\circ} \mathrm{F}$ (ITC 1978, p. 65), and large-scale experiments at this temperature have been proposed. Practical production of temperatures higher than $550^{\circ} \mathrm{F}$ require that higher concentration ratios and means of reducing thermal losses from the receiver be achieved. A central receiver affords these possibilities, but so far the technology has not progressed beyond the larger-scale experimental stage. However, development activity is intense for applications to electrical generation. The most ambitious project to date is the Barstow $10-\mathrm{MW}$ project involving the Department of Energy (DOE), Califomia utility companies, and industrial contractors. Considering the size-of a solar facility required for an oil refinery, the central receiver concept could be the most appropriate solar system. This could be so, even though possible solar applications do not go much beyond the $550^{\circ} \mathrm{F}$ temperature range. A central receiver has particular attractions for large systems, since much interconnecting piping and controls, as well as thermal and parasitic losses, can be eliminated. Also, there are potential economic benefits in using flat reflecting mirrors for heliostats. Thus, while direct solar thermal energy is not an alternative to the use of conventional-type fluid fuels for high-temperature refinery processes, solar-derived energy might compete with fuels for steam generation, and has potential for replacing that $25 \%$ of refinery fuel consumed at low temperatures. Such a displacement would leave a refinery fuel gap of only $15 \%$ to be filled by fucl imports, residuum, or conservation measures. Solar energy would be delivered to the process area through the use of a heat transfer fluid heated at a centralized location. The nonpolluting nature of solar energy appears to be the major advantage over coal. Coal requires sizeable amounts of land, but requirements for a solar facility are much larger.

The majority of the U.S. refining industry is located on the Gulf Coast, where annual direct solar radiation is about 5.8 billion $\mathrm{J} / \mathrm{m}^{2}\left(515,000 \mathrm{Btu} / \mathrm{ft}^{2}\right)$. The potential for solar energy amounts to 25 percent of the process heat load. The process heat load is about 80 percent of total refinery energy consumption. One strategy in designing a solar system that incorporates full energy backup facilities but no storage is to size the system such that the process lusd is delivered only during periods of peak solar radiation. This avoids the problem of having to reject heat or of having to defocus collectors. This peak for the Gulf Coast region is assumed as $800 \mathrm{~W} / \mathrm{m}^{2}\left(254 \mathrm{Btu} / \mathrm{ft}^{2}-\mathrm{h}\right)$. Thus, as shown in Table $3-1$, a solar field, reflecting advanced state-of-the-art performance parameters (deLeon et al. 1979), would occupy a land area of 243 acres. Energy supplied would be equivalent to $4.1 \%$ of the total refinery urocess heat load, or $16.3 \%$ of the tot.al solar potential. This average load fraction is very low. It indicates that the use of heat storage to increase the load factor could be of considerable benefit. Solar system costs for a 100 MBPD refinery would total $\$ 63$ million in 1979 dollars. If long-term cost goals can be reached, this cost would decline to $\$ 38$ million. Energy savings extended throughout the industry 
would be equivalent to $57,000 \mathrm{BPD}$ of fuel oil, for a total investment of $\$ 6.5$ billion at an installed cost of $\$ 15.05 / \mathrm{ft}^{2}$ of collector.

Table 3-1. SOLAR SYSTBM PARAMETBRS

\begin{tabular}{|c|c|c|}
\hline \multirow{2}{*}{$\begin{array}{l}\text { Peak Direct Insolation } \\
\text { Mean Daily Direct Solar Radiation } \\
\text { Total Refinery Energy Consumption } \\
\text { Process Heat } \\
\text { Solar Potential } \\
\text { Ground Cover Ratio } \\
\qquad \begin{array}{c} \\
.\end{array}\end{array}$} & \multicolumn{2}{|c|}{$\begin{array}{l}800 \mathrm{~W} / \mathrm{m}^{2}\left(254 \mathrm{Btu} / \mathrm{ft}^{2}-\mathrm{h}\right) \\
16 \mathrm{MJ} / \mathrm{m}^{2} / \mathrm{day}\left(1410 \mathrm{Btu} / \mathrm{ft}^{2}-\mathrm{dy}\right) \\
2.31 \times 10^{13} \mathrm{Btu} / \mathrm{yr}=2600 \times 10^{6} \mathrm{Btu} / \mathrm{h} \\
1.85 \times 10^{13} \mathrm{Btu} / \mathrm{yr}=2100 \times 10^{6} \mathrm{Btu} / \mathrm{h} \\
4.61 \times 10^{12} \mathrm{Btu} / \mathrm{yr}=527 \times 10^{6} \mathrm{Btu} / \mathrm{h} \\
25 \%\end{array}$} \\
\hline & $\begin{array}{l}\text { Advanced State- } \\
\text { of-the-Art, } 1985\end{array}$ & $\begin{array}{c}\text { Economic and Tech- } \\
\text { nological Gools } \\
1990\end{array}$ \\
\hline $\begin{array}{l}\text { Peak Efficiency (\%) } \\
\text { Net Annual Average Efficiency (\%) } \\
\text { Total Installed System Cost }\left(1979 \$ / \mathrm{ft}^{2} \text { ) }\right. \\
\left.\text { Area of Heliostats (million } \mathrm{ft}^{2} / \mathrm{acres}\right) \\
\text { Area of Solar Field (acres) } \\
\text { Energy Supplied (Btu/yr) } \\
\text { Energy Supplied ( } \% \text { total process heat) } \\
\text { Total Solar System Cost (million } 1979 \$ \text { ) }\end{array}$ & $\begin{array}{c}78 \\
55 \\
23.72 \\
2.65 / 60.9 \\
243 \\
7.5 \times 10^{11} \\
4.1 \\
63\end{array}$ & $\begin{array}{c}82 \\
60 \\
15.05 \\
2.52 / 57.9 \\
231 \\
7.8 \times 10^{11} \\
4.2 \\
38\end{array}$ \\
\hline
\end{tabular}

For refinery planning purposes, it is recommended that 5 acres per 1,000 BPD processing capacity be allocated (Gary and Handwerk 1975, p. 210). However, actual land purchased for buffer zones, future expansion, etc., is much more. Unoccupied land for 100 MBPD refineries over a full range of complexity varies from 240 to 490 acres. Thus, the quantity of land already on hand at most refineries is not out of line with the area required for solar collectors. It is also conceivable that heliostats could be located between tanks in the tank farm, although they would be subject to shading. Of less significant possibility is their location on top of the storage tanks. The tank walls should be sufficiently strong to support the loadings imposed by the heliostats. Again, the height of a central receiver is such that conceivably it could be placed within the refinery processing area.

Penetration of solar energy into the oil refining industry would displace a great deal of energy. In addition, perhaps no other industry is better equipped to provide the operating and maintenance personnel to ensure the reliable operation of a solar system.

\subsection{SYNTHETIC PUELS}

These fuels are likely to be produced in a liquid or gaseous form and thus could be easily burned in existing equipment. However, at present the technology in the U.S. has not progressed beyond the large-scale experimental stage. Alsn, transportablc fuels derived from oil shale and coal are likely to be superior in quality and more valuable than 
refinery-derived residuum. Low-quality fuels, such as producer gas from coal, would have to be produced near the refinery. Overall, synthetic fuels are not regarded as an alternative to conventional refinery fuel sources. 


\section{SECTION 4.0}

\section{CONCLUSIONS}

This report has surveyed the major energy-consuming processes in an oil refinery. Comparisons have been made to other reports covering this topic, and the feasibility of employing alternatives to existing refinery fuel sources has been investigated. The following conclusions can be drawn:

- The potential for fuel displacement in refineries is approximately $40 \%$ of total energy requirements, made up of about $28 \%$ natural gas and $12 \%$ fuel oil.

- By assigning a single temperature to individual refinery processes, previous IPH studies of the on refining industry have overemphasized high-temperature requirements. This paper estimates that $22 \%$ of refinery process heat is generated in fired heaters at temperatures below $550^{\circ} \mathrm{F}$, and that $63 \%$ is generated between $550^{\circ}$ and $1100^{\circ} \mathrm{F}$.

- In the foreseeable future, there is unlikely to be any technically feasible alternative to conventional-type fluid fuels to supply process temperatures above $700^{\circ} \mathrm{F}$.

- There is little potential for solar energy to provide process heat to any of the U.S. market in the temperature range $700-1100^{\circ} \mathrm{F}$.

- Future curtailments of natural gas supplies and advances in "bottom of the barrel" oil processing technology could produce strong incentives to develop alternatives to the burning of liquid fuels for low-temperature processes.

- Either coal or solar energy (or a combination of both) could be used to supply low-temperature requirements below $700^{\circ} \mathrm{F}$. Heat would be delivered through the use of a heat transfer medium to exchangers in the process area. Such fuel sources could also be used for refinery steam production.

- The cost of installing coal-burning equipment can be up to eight times the cost of gas- or oil-burning facilities. However, the major obstacle to the use of coal is environm ental.

- On a year-round basis, a central receiver solar energy system without storage, sized to deliver a maximum of $25 \%$ of process heat requirements could displace about $4.1 \%$ of refinery fuel needs. For the entire industry, this is equivalent to $57,000 \mathrm{BPD}$ of fuel oil. If long-term cost goals are achieved, the capital cost of solar systems to displace such quantities of fuel oil would be $\$ 6.5$ billion.

- A central receiver facility to supply the maximum potential quantity of solar energy to a 100,000 BPD refinery, without storage, would occupy about 240 acres. Such an area is not out of line with land currently vacant at refineries. 


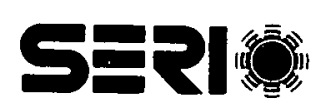




\section{SECTION 5.0}

\section{REPERENCES}

Aerospace Corporation! 1978. High Temperature Industrial Process Heat. Technology Assesment and Rationale. El Segundo, CA (Prepared for DOE).

American Petroleum Institute. 1977. Basic Petroleum Data Book. Washington, D.C.

Battelle Columbus Laboratories. 1977. Survey of the Applications of Solar-Thermal Energy Systems to Industrial Process Heat. 3 Vols. Columbus, OH.

Cantrell, Ailleen. 1975. Oil and Gas Journal. Vol. 74: April 7; p. 96.

Cantrell, Ailleen. 1976. Oil and Gas Journal. Vol. 74: March 29; p. 129.

Chemical Engineering. June 4, 1979, p. 71 (News Release).

de Leon, P.; Brown, K. C.; Margolis, J.; Nasr, L. 1979. Solar Technology Applications to Enhanced Oil Recovery. TR-352-392. Solar Energy Research Institute: Golden, CO.

Gary, James H.; Handwerk, Glen E. 1975. Petroleum Refining-Technology and Economics. New York: Marcel Dekker, Inc.

Gordian Associates, Inc. 1976. An Energy Conservation Target for Industry, SIC 29. 2 Vols. New York. (Prepared for the Federal Energy Office.)

InterTechnology Corporation. 1977. Analysis of the Economic Potential of Solar Thermal Energy to Provide Industrial Process Heat. 3 Vols. Warrenton, VA.

Ketels, P. A.; Reeve H. R. December 1979. Market Characterization of Solar Industrial Process Applications: Progress Report. PR-52-212. Solar Energy Research Institute: Golden, CO.

Mann, Charles E.; Heller, James, H. Coal and Profitability: An Investor's Guide. New York: Coal Week; McGraw-Hill Pub. Co.

Solar Thermal Test Facilities Users Association. 1978. Proceedings of Solar HighTemperature Industrial Processes Workshop. Atlanta, GA; September 28-30.

Thermo Electron Corporation. June 1976. A Study of Inplant Electric Power Generation in the Chemical, Petroleum Refining, and Paper and Pulp Industries. U.S. Dept. of Commerce, National Technical Information Service PB-255 659. 


\begin{tabular}{|c|c|c|}
\hline $\begin{array}{l}\text { Document Control } \\
\text { Page }\end{array}$ & $\begin{array}{r}\text { 1. SERI Report No. } \\
\text { TR-733-562 }\end{array}$ & 3. Recipient's Accession No. \\
\hline 4. Title and Subtitle & d the Oil Refining Industry & $\begin{array}{l}\text { 5. Publication Date } \\
\qquad \text { March } 1980\end{array}$ \\
\hline \multicolumn{2}{|c|}{ Solar Energy and the Oil Refining Industry } & 6. \\
\hline \multicolumn{2}{|c|}{ 7. Author(s) } & 8. Periorming Organization Rept. No. \\
\hline \multicolumn{2}{|c|}{$\begin{array}{l}\text { Solar Energy Research Institute } \\
1617 \text { Cole Boulevard } \\
\text { Golden, Co } 80401\end{array}$} & $\begin{array}{l}\text { 10. Project/Task/Work Unit No. } \\
\text { Task 非 } 3473.20 \\
\text { 11. Contract (C) or Grant (G) No. } \\
\text { (C) } \\
\text { (G) }\end{array}$ \\
\hline \multirow{2}{*}{\multicolumn{2}{|c|}{ 12. Sponsoring Organization Name and Address }} & $\begin{array}{l}\text { 13. Type of Report \& Perioo Covered } \\
\text { Technica1 Report }\end{array}$ \\
\hline & & 14. \\
\hline
\end{tabular}

15. Supplementary Notas

16. Abstract (Limit: 200 words) This paper surveys process heat requirements of the major petroleum refinery processes. Previous studies have overestimated requirements for process heat at high temperatures. About $22 \%$ of the process heat in a refinery is consumed below $550^{\circ} \mathrm{F} ; 62.5 \%$ is consumed between $550^{\circ}$ and $1100^{\circ} \mathrm{F}$. A refinery gets about $40 \%$ of its total energy supply, \& $50 \%$ of its process heat, from natural gas \& fuel oil. Technological constraints limit the use of alternatives such as coal or solar energy to processes operating below $700^{\circ} \mathrm{F}$ (about $25 \%$ of process heat requirements). Curtailments of natural gas supplies \& advances in "bottom of the barre1" oil processing technology will produce strong incentives to develop alternatives to the burning of liquid fuels for low-temperature processes. Energy from coal or solar radiation is most appropriately generated at a central facility to heat a heat transfer fluid, which is then heat exchanged with the process medium. The same process could also produce steam. The cost of installing coal-burning equipment can be up to eight times the cost of the equivalent gas or oil-burning facility. The major obstacle to the use of coal is environmental. An analysis of a central-receiver solar system, without storage, \& sized to deliver a maximum of $25 \%$ of process heat needs, indicates that $4.1 \%$ of refinery fuel needs could be displaced. For the entire industry, this is equivalent to 57,000 BPD of fuel oil. If long-term cost goals are achleved, capital expenditures to realize these savings would amount to $\$ 6.5$ hillion.

17. Document Analysis

a. Descriptors Petroleum Refineries; Process Heat; Fuels; Solar Energy, Synthetic Fuels; Coal; Energy Conservation

b. Identifiers/Open-Ended Terms

¿. UC Categories

$\mathrm{UC}-58 \mathrm{~b}, 59 \mathrm{~b}, 92$

18. Availability Statement

National Technical Information Service

U. S. Department of Commerce

5285 Port Royal Road

Springfield, Virginia 22161

Form No. 8200-13 (6-79)

\begin{tabular}{|c|}
\hline 19. No. of Pages \\
33 \\
\hline 20. Price $\$ 4.50$ \\
\hline
\end{tabular}

